\title{
Legal aspects of digitalization of public procurement system in the Russian Federation
}

\author{
By \\ Dr. Olga A. SERGACHEVA \\ PhD in Law, Head of the Department of Civil Law \\ Disciplines - Volgograd Institute of Management, branch \\ of Russian Presidential Academy of National Economy and \\ Public Administration \\ Volgograd, Russian Federation \\ Correspondence: utro1@yandex.ru
}




\begin{abstract}
Public procurement is one of the priority areas of economic development in the Russian Federation due to the need to ensure targeted and efficient spending of budget funds. Without a doubt, the use of innovative digital tools in the procurement sector will lead to an increase in the quality of public procurement. The purpose of this study is to analyze the digitalization prospects of public procurement, highlighting the main stages of digitalization of public procurement in the Russian Federation, methods of using digital tools in the procurement of goods, work, services for state and municipal needs. The article also explores the possibility of using distributed ledger technology (blockchain) in public procurement in Russia. The methodological basis of the study was made up of both general scientific and private scientific methods of cognition. As a result of the study, the author concludes that three main stages of digitalization of the public procurement sphere in the Russian Federation can be distinguished and that the use of digital innovative tools (in particular, blockchain technology) for public procurement will increase the efficiency of budget spending.
\end{abstract}

Keywords: digitalization; public procurement; Russian Federation; stages of digitization, smart contract. 


\section{Introduction}

The effective functioning of the public procurement system is extremely important for the stable development of the national economy and the construction of interstate trade interaction. Such functioning in the era of global digitalization should be subordinated to world trends of opening the borders of markets and establishing economic interaction. In this context, the digitalization of public and municipal procurement in Russia seems to be the most important process, the legislative support of which should be carried out taking into account international experience in this area.

Public procurement is key to the global economy. Thus, Zornitsa Kutlina-Dimitrova in his study notes: "Concerning economic significance worldwide, public procurement amounts to a double-digit share of gross domestic product (GDP) in most developed countries." (Kutlina-Dimitrova, 2018).

At the same time, the digitalization of public procurement is a worldwide trend. For example, in the Communication of the Commission of the European Parliament, made in Strasbourg on October 03, 2017 (Comunicazione, 2017), it is noted that new digital technologies represent great opportunities to simplify procurement procedures for public needs. Only if the entire 
procurement procedure is digitally transformed will it be possible to take full advantage of the benefits of electronic procurement. These transformations include various stages: from planning, notification, and presentation to invoicing, payment and, ultimately, storing all these data in digital archives. New technologies provide an opportunity to radically rethink the organization of public procurement.

S. Issabayeva, B. Yesseniyazova, and M. Grega note that "Epublic procurement has a great potential to improve public procurement processes. It helps to increase competitiveness, and the use of digital technologies also minimizes transaction costs for business, increases trust and the transparency of decisions made by public customers" (Issabayeva, Yesseniyazova, Grega, 2019).

\section{Materials and methods}

To conduct this study, we used the method of dialectical research (studying the object in its dynamic development), as well as the method of comparison, analysis, and synthesis. To obtain the most reliable results of the study, the classification method is also used. 


\section{Literature Review}

During the study, the author investigated numerous sources, the analysis of which led to the conclusions formulated at the end of this article. To study the aspects related to the legal regulation of public procurement in Russia and abroad, as well as the features and prerequisites for introducing individual digital instruments into the procedures for such procurement, the regulatory legal acts, and their projects were analyzed. Thus, the author examined the theses of the Digital Economy of the Russian Federation program, approved by Order of the Government of the Russian Federation of July 28, 2017 No. 1632-r; Federal Law of 05.04.2013 No. 44-FZ "On the contract system in the field of procurement of goods, works, services to ensure state and municipal needs", draft of Federal Law No. 419059-7 "On Digital Financial Assets" dated January 25, 2018, Decree of the Government of the Russian Federation of September 30, 2014 No. 996 "On the distribution of powers between the Ministry of Economic Development Of the Russian Federation and the Federal Treasury in the creation of a unified information system in the field of procurement", Decree of the Government of the Russian Federation of January 23, 2015 No. 36 "On the procedure and deadlines for putting into operation a unified information system in the field of procurement." 
The scientific and theoretical basis was the research of foreign (Kutlina-Dimitrova Z. (2018), Issabayeva S., Yesseniyazova B., Grega M. (2019), Piselli P. (2019), Di Guida (2018)) and Russian (Savelyev AI (2017), Sergacheva O.A. (2018), Gladilina I.P. (2019), Afanasiev M., Rachenko I. Arbuzov M. (2019) researchers who conducted diverse studies in the field of e-procurement and the impact on the improvement of this system of the digitalization process.

\section{Results}

As noted in the World Bank Group's Review "Digital Agenda of the Eurasian Economic Union until 2025 (Overview, 2018): Prospects and Recommendations", the effect of digitalization of public procurement at the regional level (EAEU) is estimated at $\$ 16.3$ billion.

Thus, improving the regulation of public procurement, including using digital tools, is becoming increasingly apparent. Let us see how in Russia over the past few decades, the digitalization process has had an impact on public procurement. There is no doubt that "all spheres of socio-economic development of Russia are impacted by the use of digital technologies" (Gladilina, 2019). In this regard, it should be noted that the reform of the public 
procurement system in the context of the general digitalization trend of the Russian economy takes place in several stages.

From the point of view of the evolution of legal regulation of the use of digital tools in public procurement procedures, three main stages are the following:

1) the introduction of information technology in the process of state and municipal procurement by creating a specialized website on the Internet, digitalizing an open auction, introducing the massive use of unqualified electronic digital signatures by participants in the contract system;

2) digitalization of the vast majority of procurement procedures, the introduction of mass use of enhanced qualified electronic digital signatures by participants in the contract system, and the change in the rules for working with electronic trading floors;

3) introduction of specific digital technologies into the procurement process, in particular, blockchain technology (at the level of conferences and bills). 
Olge A. Sergacheva . عدد خاص بالمؤتمر الدولى السنوى العشرون

From the point of view of the level of applied digital technologies, it seems possible to distinguish two main stages:

1) the use of fairly widespread digital technologies, mainly related to work on the Internet, the use of various specialized sites, cryptographic encryption keys (Unified procurement information system, electronic trading platforms, confirmation of actions and document verification by electronic digital signature).

2) introduction of innovative digital technologies into the sphere of state and municipal procurements, which have not received a widespread practical application in the Russian Federation today (in particular, the technology of distributed registries - blockchain).

The second classification is mainly applied and technical in nature, therefore, a detailed analysis of the stages identified in the first classification should be considered the main one.

The first stage of digitalization in the sphere of ensuring state and municipal needs in the Russian Federation was marked by the creation of a single information portal for all public customers: a website on the Internet called the "Unified Information System in the Procurement Sector." The creation and functioning of the 
system were determined by the need to provide information support for the contract system in the field of procurement, the implementation of the project was regulated by several regulatory legal acts (Federal law No.44-FZ). Today, the Federal Treasury of Russia (Decree of the Government, 2017) is the single federal executive body responsible for the functioning of the procurement information system. According to paragraph 9 of Article 3 of Law No. 44-FZ, a unified information system in the field of procurement is the totality of information provided for by the norms of this law and contained in databases, information technologies and technical means ensuring the formation, processing, storage of such information, as well as its providing, using the official website, a unified information system in the Internet telecommunication network. In paragraph 3 of Art. 4 of Law No. 44-FZ lists the information contained in the UIS. It is an array of information covering the stages of procurement for public needs or necessary and is used for their implementation: procurement planning, identification of suppliers (contractors, contractors), the conclusion of public contracts and their implementation, monitoring of procurement of goods, works, services, audit in the field of goods, works, services, monitoring compliance with laws and other 
regulatory legal acts on the contract system of the Russian Federation.

It should be noted that the Unified Information System in the Procurement Sector, which facilitates public procurement and the development of the procurement contract system as a whole, is an effective digital tool, the development prospects of which are quite obvious. The digitalization of procurement procedures also contributes to increasing the efficiency of providing state and municipal needs, while significantly increasing budgetary savings. The digitalization of procurement procedures combines the two stages that we have identified above. At the first stage, only the open auction procedure was transferred to electronic form. Statistics show that among all the procurement methods to meet state and municipal needs, the first place in the frequency of holding is held by an open auction in electronic form.

Taking into account the successful experience of transferring an open auction into electronic form by the legislator, measures are being taken to legislatively consolidate digitalization and other ways to determine the best supplier (contractor). Given the upcoming reform of the public procurement system in this context, these measures will be analyzed as part of the second stage of the introduction of digital technologies in the system of public and 
municipal procurement in Russia. First of all, it is necessary to note the Federal Law adopted at the end of 2017 dated December 31, 2017, No. 504-Ф3 “On Amending the Federal Law On the Contract System in the Sphere of Procurement of Goods, Work, and Services for Ensuring State and Municipal Needs" (Federal law No.504-FZ). The specified law establishes the need for the vast majority of procurement procedures in electronic form, in particular, an open tender, a tender with limited participation, a two-stage tender, electronic auction, request for quotations, requests for proposals. Special tools are called upon to ensure the effective implementation of electronic procurement: the use by participants of procurement when signing documents of an exceptionally enhanced electronic signature (with qualified certificates of keys for verifying electronic signatures), the creation of a Unified Register of procurement participants in electronic form, the creation of a state information system on an electronic platform for monitoring purposes and fixing actions, inaction of the participants of the contract system in the field of procurement in a unified information system.

The third stage in the implementation of digital technologies in the system of state and municipal procurement in Russia (subject to legislative consolidation of the necessary implementation mechanisms) should be a qualitative change in procurement 
procedures from a technical point of view. Currently, at the discussion level, the issue of the possibility of introducing specific digital technologies (such as a distributed registry system) into the public procurement system is being considered. The effectiveness of the use of such digital tools is positively evaluated by researchers. As rightly noted in the specialized literature, in the field of state and municipal administration, the most effective use of blockchain technologies may be the formation of a single register containing the history of the placement of state and municipal orders, as well as the procurement of corporations with state participation and / or control (primarily in parts of a reliable and consistent assessment of suppliers) (Klechikov, Pryanikov, Chugunov, 2017).

Distributed registry technology (blockchain technology) means "an approach to the exchange and storage of information, in which: each participant can have a full copy of the registry; synchronization of registry copies occurs on the basis of a protocol for achieving distributed consensus, that is, agreement among participants to add new information; each interaction participant can have access to transaction history" (Bank of Russia Public Consultation Report, 2019). A.I. Savelyev highlights the following advantages of blockchain technology: "1) decentralization, which 
minimizes the risks of failure in case of failure of a separate system; 2) an increased degree of security through the use of cryptography in each transaction; 3) the impossibility of changing the blockchain data retroactively; 4) efficiency due to automated data exchange, in which there is no human factor; 5) transparency, since all actions within the blockchain are documented and available for review by all participants in the system" (Savelyev, 2017).

In the field of state and municipal procurements, distributed ledger technology can be applied, in particular, in the implementation of the mandatory procedure for securing applications for participation in the procedure for determining the best supplier (contractor) and providing contracts with winners of such procedures. Under paragraph 2 of Art. 44 of Law No. 44-FZ, the application for participation in a tender or auction may be provided by a procurement participant in the form of cash or a bank guarantee. The selection of a method for securing an application for participation in a tender or auction is carried out by the procurement participant. At the same time, practice shows that the procurement participants acknowledge the receipt of a bank guarantee as the preferred option, because, especially when concluding large contracts, not every business entity can afford to 
withdraw a large sum of money from circulation. In this regard, blockchain technology can be successfully applied to simplify the process of issuing bank guarantees. As noted in the Bank of Russia Public Consultation Report "Development of the technology of distributed registries" made in December 2017, "using a distributed registry will reduce costs and speed up the process of issuing bank guarantees, simplify the process of checking them by third parties, and also ensure access to them is differentiated" (Bank of Russia Public Consultation Report, 2019). The point of view of M. Afanasiev, I. Rachenko, M. Arbuzov that "Implementation of digital technologies in some parts of the system dealing with procurement of materials, equipment, works, and services improves business efficiency on the one hand; on the other, they are necessary and a prerequisite for further digitalization of the whole Procurement System" (Afanasiev, Rachenko, Arbuzov, 2019).

\section{Conclusions}

Thus, in the process of digitalization of public procurement in the Russian Federation, three main stages can be distinguished: the first stage is the introduction of information technology in the process of public and municipal procurement by creating a specialized website on the Internet and digitalizing an open auction, introducing mass use unqualified electronic digital signature by 
participants in the contract system. The second stage is the digitalization of the vast majority of procurement procedures, the introduction of mass use of enhanced qualified electronic digital signatures by participants in the contract system, and the change in the rules for working with electronic trading floors. The third stage is the introduction of specific digital technologies into the procurement process, in particular, distributed register technology (blockchain).

It can be stated that each of the selected stages is aimed at achieving certain goals of the development of the public procurement system in the Russian Federation, however, to achieve the maximum economic effect, it is also necessary to work on implementing the fourth stage: creating the possibility of interaction of the Russian Unified Information System in the field of procurement with similar foreign systems. Achieving these goals should mark the existence of an effective, transparent and open procurement system for Russian state and municipal needs.

\section{References}

1. Afanasiev M., Rachenko I., Arbuzov M. Role and significance of mobile technologies in digitalizationof procurement systems in oil and gas companies in IOP Conference Series: 
Olge A. Sergacheva . عدد خاص بالمؤتمر الدولى السنوى العشرون

Materials Science and Engineering. Volume 497, International Scientific Conference "Digital Transformation on Manufacturing, Infrastructure and Service" 21-22 November 2018, Saint-Petersburg, Russian Federation. Pp. 1-5.

2. Bank of Russia Public Consultation Report "Development of Distributed Register Technology" in http://www.cbr.ru/Content/Document/File/36007/reestr_surve y.pdf (accessed 13 March 2020)

3. Brykin K.I. (2018) Blockchain as a Mean of Transparency Principle Implementation in the Public Finance Sector. Financial right, 4. 2018: 39-42.

4. Comunicazione della commissione al Parlamento Europeo, al Consiglio, al Comitato economico e sociale europeo e al Comitato delle regioni. Appalti pubblici efficaci in Europa e per l'Europa. COM/2017/0572 final // https://eurlex.europa.eu/legalcontent/IT/TXT/?uri=COM\%3A2017\%3A572\%3AFIN (accessed 12 March 2020)

5. Decree of the Government of the Russian Federation of April 13, 2017 No. 442 "On the determination of the federal executive body authorized to carry out functions to develop 
functional requirements for a unified information system in the field of procurement, to create, develop, maintain and maintain a unified information system in the field of procurement, according to establishing the procedure for registration in a single information system in the field of procurement and the procedure for using a single information system in the field of procurement, and on amendments to some acts of Governments and the Russian Federation and the recognition of the Decree of the Government of the Russian Federation of September 30, 2014 No. 996 as invalid"

6. Di Guida G.M., Naticchia B., Ciribini A. (2018). Le potenzialità della blockchain nella gestione degli appalti. Il Sole 24 Ore, 25/08/2018.

7. Draft Federal Law №419059-7 On Digital Financial Assets dated 25/01/2018. available at: https://www.minfin.ru/ru/document/?id 4=121810 (accessed 13 March 2020)

8. The EAEU 2025 digital agenda : prospects and recommendations - overview report, available at: http://documents.vsemirnyjbank.org/curated/ru/850581522435 
Olge A. Sergacheva . عدد خاص بالمؤتمر الدولى السنوى العشرون

806724/pdf/EAEU-Overview-Full-ENG-Final.pdf $\quad$ accessed 13 March 2020))

9. Federal law No.44- FZ On the contract system in the field of procurement of goods, work, services to meet state and municipal needs. Dated 05/04/2013 (2013). Collection of the legislation of the Russian Federation, 04/08/2013, No. 14, Art. 1652.

10. Federal law No.504-FZOn Amendments to the Federal Law "On the Contract System in the Sphere of Procurement of Goods, Work, and Services to Ensure State and Municipal Needs". Dated 31/12/2017 (2017).Collection of the legislation of the Russian Federation, 01/01/2018, No. 1, Art. 88.

11. Gladilina I.P.Creative Thinking and Development of Professionalism byProcurement Specialists in the Context of Digitalization in Academic Journal ofInterdisciplinary Studies. Volume 8 № 2 July 2019. Pp. 219-225.

12. Issabayeva S., Yesseniyazova B., Grega M. Electronic Public Procurement: Process and Cybersecurity Issues in NISPAcee Journal of Public Administration and Policy. Volume 12, Issue 2, 1 December 2019, Pages 61-79. 
Olge A. Sergacheva . عدد خاص بالمؤتمر الدولى السنوى العشرون

13. Klechikov A.V., Pryanikov M.M., Chugunov A.V. Blockchain technologies and their use in the public sphere in International Journal of Open Information Technologies ISSN: 2307-8162 vol. 5, no.12, 2017. P. 127.

14. Legge 11 febbraio 2019, n. 12 "Conversione in legge, con modificazioni, del decreto-legge 14 dicembre 2018, n. 135, recante disposizioni urgenti in materia di sostegno $\mathrm{e}$ semplificazione per le imprese e per la pubblica amministrazione. GU Serie Generale n.36, 12/02/2019.

15. Ministerial Declaration on the Digital Economy: Innovation, Growth and Social Prosperity ("Cancún declaration"), available at: https://www.oecd.org/sti/ieconomy/DigitalEconomy-Ministerial-Declaration-2016.pdf $\quad$ (accessed 11 March 2020)

16. Order of the Government of the Russian Federation № 1632-P On approval of the program "Digital Economy of the Russian Federation" dated 28/07/2017. Government.ru: http://government.ru/docs/28653/ (accessed 13 March 2020)

17. Overview of the World Bank Group "Digital Agenda of the Eurasian Economic Union until 2025: Prospects and Recommendations"http://www.eurasiancommission.org/ru/act 
Olge A. Sergacheva . عدد خاص بالمؤتمر الدولى السنوى العشرون

/dmi/SiteAssets/\%D0\%9E\%D0\%B1\%D0\%B7\%D0\%BE\%D1 \%80\%20\%D0\%92\%D0\%91.pdf (accessed 14 March 2020)

18. Piselli P. (2018) Blockchain e cognitive procurement nella contrattualistica pubblica. available at: https://www.agendadigitale.eu/procurement/blockchain-perleprocurement-ecco-le-nuove-frontiere-degli-appalti-pubblici/ (accessed 14 March 2020)

19. Protocol decision of the CIS Economic Council "On the formation of competition policy in the CIS member states in the context of the development of the digital economy (Adopted in Moscow on 12/07/2018).

20. Risoluzione del Parlamento europeo del 3 ottobre 2018 sulle tecnologie di registro distribuito e blockchain: creare fiducia attraverso la disintermediazione (2017/2772(RSP)) available at: http://www.europarl.europa.eu/sides/getDoc.do?pubRef =/EP/NONSGML+TA+P8-TA-20180373+0+DOC+PDF+V0/IT (accessed 13 March 2020)

21. Savelyev A.I. (2017) Some legal aspects of the use of smart contracts and blockchain technologies in Russian law in Law. 2017. N 5, pp. 94 - 117. 
Olge A. Sergacheva . عدد خاص بالمؤتمر الدولى السنوى العشرون

22. Sergacheva O.A. (2017) "Legal Regulation of Procurement by the National (Government) Companies in Italy" in "Public procurement in foreign countries: the dynamics of legal regulation: monograph" Resp. ed. O.A. Belyaeva, V.A. Vaipan, K.V. Kichik. - Moscow. Justicinform. Pp. 228-268. 